\title{
Pelatihan Mengelola Homestay di Desa Wisata Donokerto
}

\author{
Fian Damasdino ${ }^{1}$, Parsidi ${ }^{2}$, Arif Dwi Saputra ${ }^{3}$, Nikasius Jonet Sinangjoyo ${ }^{4}$, Angela \\ Ariani $^{5}$, Hamdan Anwari ${ }^{6}$, Mona Erythrea Nur Islami ${ }^{7}$ \\ 12,3,4,5,6,7Sekolah Tinggi Pariwisata AMPTA, Yogyakarta, Indonesia, Email: \\ fian@ampta.ac.id
}

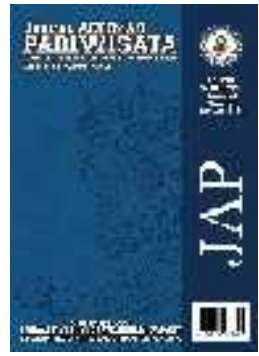

\begin{tabular}{ll}
\hline \multicolumn{2}{l}{ Informasi artikel } \\
\hline $\begin{array}{ll}\text { Sejarah } \\
\text { artikel }\end{array}$ & \\
Diterima & $: 26$ Juli 2019 \\
Revisi & $:$ 3 Agustus 2019 \\
Dipublikasikan & $:$ 15 Januari 2020 \\
\hline
\end{tabular}

\section{Kata kunci:}

Homestay

Tata kelola

Pelayanan
Desa Donokerto

\begin{abstract}
ABSTRAK
Desa Donokerto merupakan salah satu rintisan desa wisata yang memiliki potensi cukup bagus dari segi keanekaragaman daya tarik wisata. Selain daya tarik wisata, sebagai faktor utama pemicu kunjungan, Homestay merupakan salah satu sumber pendapatan utama yang sangat strategik untuk diperhitungkan dalam setiap kepengelolaan desa wisata.Mengingat Homestay merupakan kebutuhan dasar bagi setiap wisatawan yang ingi berkunjung untuk menikmati daya tarik desa dalam waktu yang lebih lama.Sebagai desa wisata yang sedang dirintis, Desa Donokerto belum memiliki sumber daya manusia atau masyarakat yang paham dalam seluk beluk kepengelolaan Homestay. Oleh karena itu, Sekolah Tinggi Pariwisata AMPTA Yogyakarta bekerja sama dengan PUM Netherlands Senior Experts mengadakan pengabdian masyarakat dengan tema "Pelatihan Mengelola Homestay di Desa Donokerto”. Kegiatan pengabdian masyarkat ini dilakukan dengan metode presentasi dan selanjutnya diikuti diskusi panel. Rekomendasi dari kegiatan pengabdian ini adalah pengelolaan homestay yang tepat menjadi faktor krusial dalam menciptakan desa wisata yang aman, nyaman, dan ramah wisatawan. Untuk itu diharapkan masyarakat dalam mengelola homestay harus memenuhi kriteria aspek produk, pelayanan, dan pengelolaan.
\end{abstract}

\section{Keywords: \\ Homestay \\ Management \\ Service \\ Donokerto Vilage}

\begin{abstract}
Managing Homestay Training in the Tourism Village of Donokerto. Donokerto Village is one of the pioneering tourist villages that has quite good potential in terms of diversity of tourist attractions. In addition to tourist attractions, as the main factor triggering a visit, Homestay is one of the main sources of income which is very strategic to be taken into account in every management of a tourist village. Remembering Homestay is a basic need for every tourist who wants to visit to enjoy the attraction of the village in a longer time As a tourism village that is being pioneered, Donokerto Village does not yet have human resources or a community that understands the ins and outs of Homestay management. Therefore, AMPTA Yogyakarta College of Tourism in collaboration with PUM Netherlands Senior Experts held community service with the theme "Training of Managing Homestays in Donokerto Village". The community service activities were carried out using the presentation method and then followed by a panel discussion. The recommendation from this community service activity is that proper homestay management is a crucial factor in creating a safe, comfortable and tourist-friendly tourist village. For this reason, it is expected that the community in managing homestays must meet the criteria for aspects of products, services, and management.
\end{abstract}

Copyright @2020 Sekolah Tinggi Pariwisata AMPTA. All Right Reserved

\section{Pendahuluan}

Pariwisata merupakanfenomena inverse jika ditinjau dari sudut pandang sosiologi (Pitana, 2012). Fenomena inversi dapat terjadi karena pada dasarnya seseorang memiliki kencederungan untuk keluar 
dari rutinitas serta lingkungannya sehari-hari menuju lingkungan yang berbeda, baru ataupun unik.Sehingga setiap daerah tujuan wisata harus mampu menunjukan ciri keunikanya yang dapat menarik wisatawan untuk berkunjung (Hermawan \& Brahmanto, 2018). Keunikan tersebut dapat berupa kondisi alam, social-budaya masyarakat, kuliner, atau sebuah bangunan buatan yang mampu menjadi landmark(Hermawan \& Gani, 2019).

Desa Donokerto merupakan salah satu desa yang sedang mengembangkan potensi wisatanya untuk bersiap menjadi Desa Tujuan Wisata. Desa Donokerto memiliki penduduk sebanyak 9.924 jiwa yang memiliki corak hidup masyarakat pedesaan yang masih kental, mayoritas penduduk memiliki pekerjaan utama sebagai petani (https://id.mwikipedia.org). Faktor alam juga menjadi keunikan tersediri bagi Desa Donokerto, daya dukung lingkunganya yang masih alami dengan sumber air bersih yang melimpah menjadikan daerah ini likasi yang subur bagi tanaman salak pondoh, buah yang menjadi produk buah unggulan Kabupaten Sleman. Daerah ini juga termasuk lokasi yang ideal untuk perkembangan perikanan dan peternakan lain.Berdasarkan segala potensi yang ada, dapat dikatakan bahwa Desa Donokerto memiliki peluang yang cukup baik untuk berkembang menjadi desa wisata unggulan.

Selain daya tarik wisata sebagai faktor utama pemicu kunjungan, Homestay merupakan salah satu sumber pendapatan utama yang sangat strategik dalam setiap kepengelolaan desa wisata karena Homestay merupakan kebutuhan dasar bagi setiap wisatawan yang ingi berkunjung untuk menikmati daya tarik desa dalam waktu yang lebih lama. Oleh karena itu, pengelolaan Homestay yang tepat menjadi faktor krusial dalam menciptakan desa wisata yang aman, nyaman dan ramah.

Sebagai desa wisata yang sedang dirintis, Desa Donokerto belum memiliki sumber daya manusia atau masyarakat yang paham dalam seluk beluk kepengelolaan Homestay. Oleh karena itu, Sekolah Tinggi Pariwisata AMPTA Yogyakarta bekerja sama dengan PUM Netherlands Senior Expertsmengadakan pengabdian masyarakat dengan tema "Pelatihan Mengelola Homestay di Desa Donokerto". Selain faktor kebutuhan di lapangan, pemilihan tema pelatihan Homestay juga dalam rangka mendukung program pemerintah 100.000 Homestay di desa wisata sampai tahun 2019 (CNN Indonesia, 2017).

Mengingat pengabdian masyarakat ini baru masih pada tahap awal, maka peningkatan pengetahuan masyarakat tentang pengelolaan Homestay serta pengetahuan tentang segala hal yang harus dipersiapkan dalam memulai usaha jasa Homestay menjadi output yang diaharapkan dari kegiatan pengabdian ini.

\section{Metode}

Kegiatan pengadian kepada masyarakat ini dilakukan di Desa Donokerta secara bertahapKecamatan Turi, Kabupaten Sleman, Daerah Istimewa Yogyakarta. Tahap pertama adalah tahap identifikasi masalah yang dilakukan pada tanggal 1 Mei 2019 sampai pada tanggal 30 Mei 2019, pada tahap ini dilakukan identifikasi terhadap potensi Desa Donokerto beserta berbagai permasalahan yang ada. Tahap kedua adalah membentuk grup diskusi untuk menentukan permasalahan yang paling krusial serta kegiatan pengabdian yang akan dilaksanakan sehingga dipilih beberapa kegiatan yang salah satunya adalah pelathian pengelolaan Homestay. Tahap kegitan adalah penyampaian gagasan kepada partisipan yaitu masyarakat serta tokoh-tokoh pengambil kebijakan di Desa Donokerto dengan bentuk kegiatan diskusi panel dengan tata cara sebagai berikut:

1. Narasumber 1 menyampaikan informasi tentang pedoman penyelenggaraan Homestay

2. Narasumber 2 menyampaikan informasi tantang perbedaan pengelolaan Homestay dan hotel termasuk hambatan dan solusi dalam pelayanan jasa penginapan.

3. Diskusi panel (tanya jawab)

4. Penyampaian kesimpulan dan rangkuman.

\section{Hasil dan Pembahasan}

Desa Donokerto yang terletak di Kecamatan Turi, Kabupaten Sleman, Daerah Istimewa Yogyakarta. Desa Donokerto memiliki 16 padukuhan yaitu Padukuhan Surodadi, Padukuhan Karanganyar, Padukuhan Randusongo, Padukuhan Gabungan, Padukuhan Dukuh, Padukuhan Donoasih, Padukuhan Gondang, Padukuhan Jamboran, Padukuhan Kenaruhan, Padukuhan Gading 
Kulon, Padukuhan Gading Wetan, Padukuhan Klegung, Padukuhan Turi, Padukuhan Ngemplak, Padukuhan Balong, dan yang terakhir Padukuhan Bandaran.

Desa Donokerto memiliki luas wilayah 742 hektar dengan ketinggian 412 meter diatas permikaan laut. Topografi terdiri dari daerah dataran tinggi dan berbukit-bukit, dengan kawasan tanah pertanian seluas 400 hektar, kawasan tanah pekarangan 100 hektar, dan luas tanah fasilitas 42 hektar. Produk perkebunan desa Donokerto adalah salak pondoh, yaitu jenis buah salak khas dari Kabupaten Sleman. Sedangkan produk peternakan utama adalah sapi, domba, unggas, ikan konsumsi, dan lain sebagainya.

Penduduk Desa Donokerto sejumlah 9.924, yang terdiri dari penduduk perempuan dengan jumlah 5.034 jiwa atau 50,72\% sedangkan penduduk laki-laki 4.890 jiwa atau 49,27\%. Mayoritas mata pencaharian penduduk Desa Donokerto adalah petani dengan jumlah 2.232 jiwa atau 49,97\%, disusul Aparatur Sipil Negara (ASN) 975 jiwa atau 21,83\%, dan pegawai swasta sejumlah 496 atau 11,10\%, sedangkan profesi lain sisanya hanya sebesar 761 jiwa atau 34,09\%. Sedangkan dari segi pendidikan mayoritas pendududuk memiliki tingkat pendidikan SLTA.

Berdasarkan gambaran geografis dan demografis diatas dapat terlihat bahwa masyarakat Desa Donokerto merupakan masyarakat pedesaan yang memiliki ciri khas keunikan tersendiri yang mampu menarik kunjungan wisatawan khsusnya wisatawan yang berasal dari perkotaan. Untuk dapat menikmati daya tarik alam dengan optimal serta dapat berinteraksi langsung dengan budaya masyakat lokal, umunya wisatawan yang dari perkotaan tersebut membutuhkan waktu tinggal lebih lama (live in). Maka kebutuhan tempat tinggal merupakan hal yang penting untuk disediakan.

Berbeda dengan guest house, homestaymerupakan jenis akomodasi yang populer di wilayah perkotaan maupun pedesaan di Indonesia, menggunakan rumah tinggal pribadi sebagai tempat wisatawan menginap. Umumnya,homestaymemberikan pelayanan kamar beserta makanan dan minuman. Salah satu kelebihan dari Homestayadalah wisatawan bisa mendapatkan kesempatan untuk mengenal keluarga pemilik. Mereka bisa juga mengenal lebih jauh tentang alam dan budaya sekitar terutama bila si pemilik rumah memiliki banyak pengetahuan tentang itu (Ningrum dkk., 2019 dan Hermawan, H dkk., 2018).Homestay digambarkan sebagai bentuk lain dari akomodasi yang melibatkan wisatawan untuk tinggal bersama keluarga yang terpilih dimana mereka bisa berhubungan dan melakukan kegiatan yang dilakukan keluarga tersebut sehari-hari(Jamaludin dkk., 2010).

Homestay merupakan salah satu sumber pendapatan utama yang sangat strategik dalam setiap kepengelolaan desa wisata karena homestay merupakan kebutuhan dasar bagi setiap wisatawan yang ingi berkunjung untuk menikmati daya tarik desa dalam waktu yang lebih lama. Oleh karena itu, pengelolaan homestay yang tepat menjadi faktor krusial dalam menciptakan desa wisata yang aman, nyaman, dan ramah, serta semuanya harus menjadi pemahaman bagi masyarakat selaku calon pelaku pariwisata di Desa Donokerto.Hal penting yang harus dipahamkan kepada masyarakat dalam mengelola homestay adalah aspek produk, pelayanan dan pengelolaan, seperti dijabarkan pada gambar-gambar berikut:

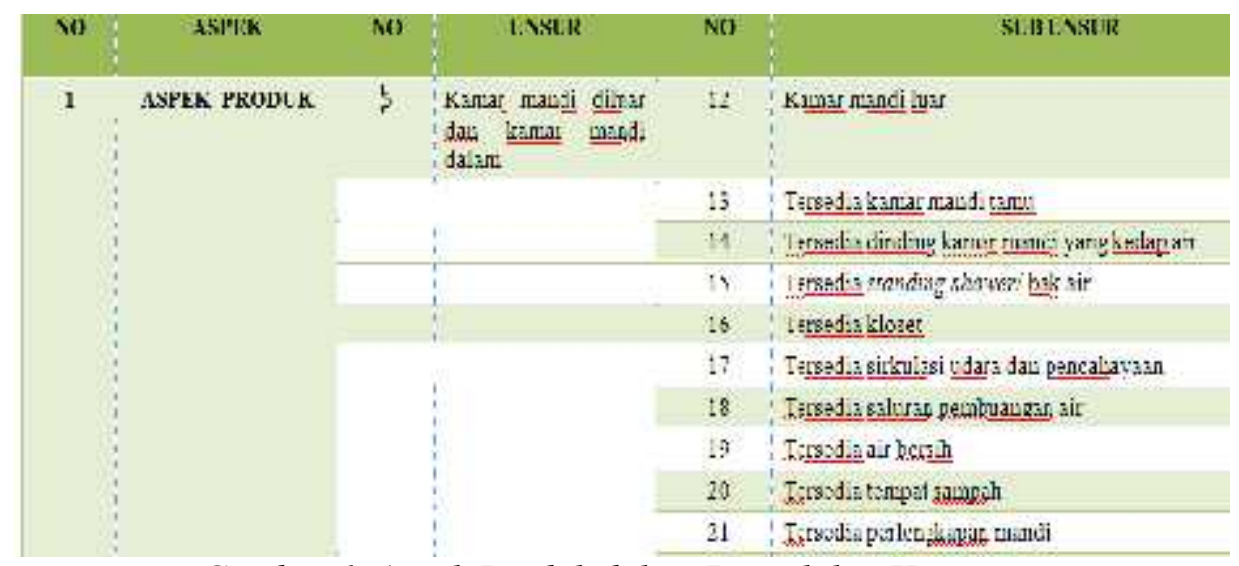

Gambar 1. Aspek Produk dalam Pengelolan Homestay

Sumber: Pedoman Pengelolaan Homestay di DIY (2015)

Berdasarkan gambar 1 maka dapat dilihat bahwa unsur utama yang harus ada dalam produk homestay adalah kamar mandi dengan berbagai kelengkapan dan hal lain yang harus diperhatikan (sub unsur) 
seperti: tersedia kamar mandi tamu, dinding harus kedap air, tersedia standing shower atau bak air, tersedia kloset (kloset duduk lebih baik), sirkulasi udara dan pencahayaan cukup, tersedia saluran pembuangan air yang berfungsi baik, tersedia tempat sampah dan kelengkapan mandi (guest supplies).

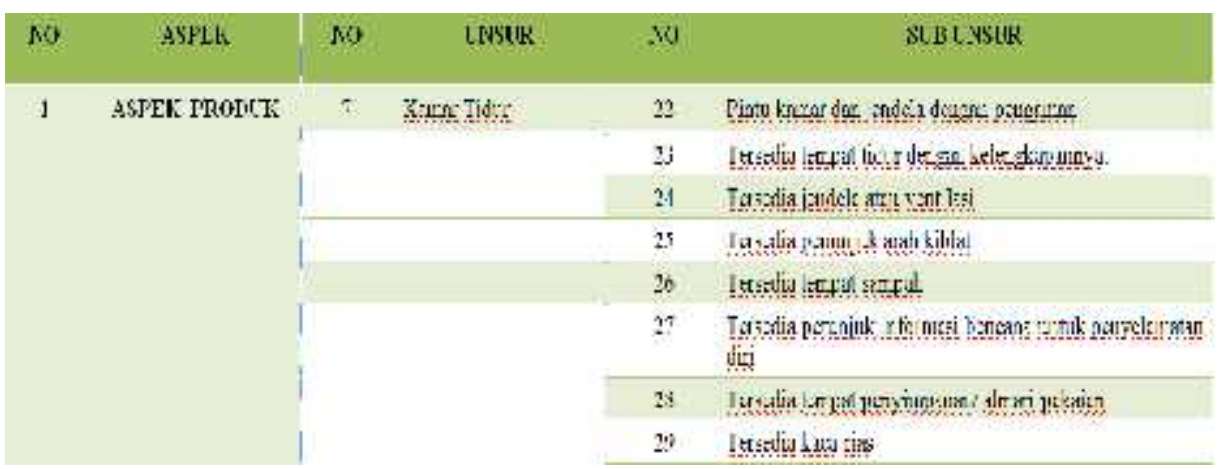

Gambar 2. Aspek Produk dalam Pengelolan Homestay Sumber: Pedoman Pengelolaan Homestay di DIY (2015)

Berdasarkan gambar 2 maka dapat dilihat bahwa unsur utama yang harus ada dalam produk homestay adalah kamar tidur dengan berbagai kelengkapan dan hal lain yang harus diperhatikan (sub unsur) seperti: pintu atau jendela dengan pengaman (kunci), tempat tidur dengan segala kelengkapanya, tersedia jendela dan ventilasi udara yang berfungsi baik, penunjuk arah kiblat, tersedia tempat sampah, tersedia penunjuk arah untuk penyelamatan diri dikala bencana, tersedia almari pakaian dan kaca rias.

\begin{tabular}{|c|c|c|c|c|c|}
\hline IIP & $\triangle 5 P T E$ & $\mathrm{ko}$ & LIXSIR & 10 & SIBCTISIR \\
\hline \multirow[t]{6}{*}{1} & \multirow[t]{6}{*}{ ASPFlK PRolJLK } & ; & 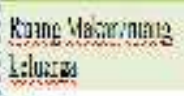 & sil & 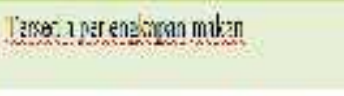 \\
\hline & & & & is & 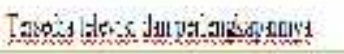 \\
\hline & & & & 22 & 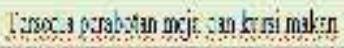 \\
\hline & & & & ii & 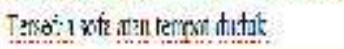 \\
\hline & & & & 9 & 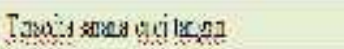 \\
\hline & & & & 35 & 'zags: 1 ir mircon \\
\hline
\end{tabular}

Gambar 3. Aspek Produk dalam Pengelolan Homestay

Sumber: Pedoman Pengelolaan Homestay di DIY (2015)

Berdasarkan gambar 3 maka dapat dilihat bahwa unsur utama yang harus ada dalam produk homestay adalah ruang makan dengan berbagai kelengkapan dan hal lain yang harus diperhatikan (sub unsur) seperti: Tersedia perlengkapan makan yang bersih, televise dan perlengakapnnya, perabotan meja dan kursi, sofa atau tempat duduk jenis lain, teredia sarana cuci tangan, air minum yang selalu tersedia.

\begin{tabular}{|c|c|c|c|c|c|}
\hline प10 & $4 S P Z$ & No & T:SIR & 10. & SUD CASTR \\
\hline \multirow[t]{7}{*}{1} & \multirow[t]{7}{*}{ ASPCK FEODCK } & 9 & Gudsnge & is & 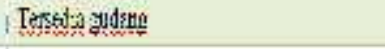 \\
\hline & & \multirow[t]{6}{*}{ (1) } & \multirow[t]{2}{*}{ Dreur } & 37 & Texstacos? \\
\hline & & & & is & lemelatang sanguth \\
\hline & & & 1 & 39 & 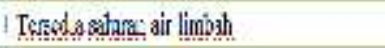 \\
\hline & & & 1 & t) & 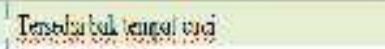 \\
\hline & & & \multirow[b]{2}{*}{1} & 1) & 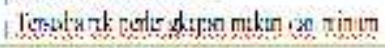 \\
\hline & & & & 12 & 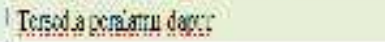 \\
\hline
\end{tabular}


Gambar 4. Aspek Produk dalam Pengelolan Homestay

Sumber: Pedoman Pengelolaan Homestay di DIY (2015)

Berdasarkan gambar 4 maka dapat dilihat bahwa unsur utama yang harus ada dalam produk homestay adalah gudang dan dapur dengan berbagai kelengkapannya yang harus diperhatikan (sub unsur) seperti: tempat sampah, saluran air limbah, tersedia bak tempat cuci, tersdia rak untuk menyimpan perlengakapn makan minum, serta peralatan dapur lain yang biasanya dibutuhkan.

Selain kelengkapan, kebersihan homestaydalam aspek produk juga perlu, karena homestay merupakan salah satu akomodasi yang diberikan untuk wisatawan yang sedang atau yang ingin melakukan kegiatan wisata di suatu kawasan.

\begin{tabular}{|c|c|c|c|c|c|c|}
\hline 80 & ASPIK & 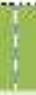 & vo & IIKan & min & SIMTINSIR \\
\hline \multirow[t]{7}{*}{2} & \multirow[t]{7}{*}{ PHIAYAKAY } & & \multirow[t]{2}{*}{ II } & \multirow[t]{2}{*}{ Tarilur } & 43 & Pelir:nim kéulie arn \\
\hline & & $\vdots$ & & & 4 & 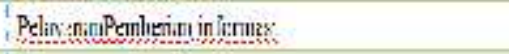 \\
\hline & & i & \multirow[t]{2}{*}{12} & \multirow[t]{2}{*}{ Triscindlix } & 15 & 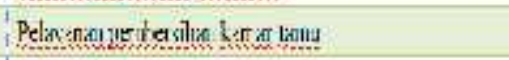 \\
\hline & & $\vdots$ & & & 45 & 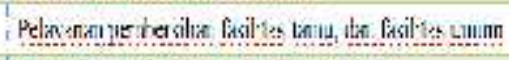 \\
\hline & & $i$ & 13 & Zngn:stolsy & $4 ?$ & 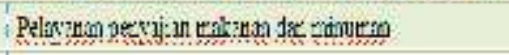 \\
\hline & & 1 & 14 & Zeandent & 48 & 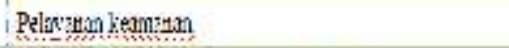 \\
\hline & & 1 & 15 & rexhlans & 4) & 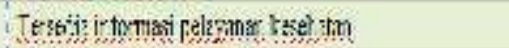 \\
\hline
\end{tabular}

Gambar 5. Aspek Produk dalam Pengelolan Homestay

Sumber: Pedoman Pengelolaan Homestay di DIY (2015)

Berdasarkan gambar 5 maka dapat dilihat bahwa unsur utama lain yang harus ada dalam pengelolaan homestayadalah pelayanan, dengan rincian sebagai berikut: kantor unutk pelayanan dan informasi, tata graha untuk pelayanan kamar dan membersihkan fasilitas tamu, ruang makan untuk penyajian makanan dan minuman, pelayanan keamanan, pelayanan kesehatan minimal tersedia obat dan alat PPPK serta akses informasi pelayanan kesehatan.

\begin{tabular}{|c|c|c|c|c|c|}
\hline in & ASFTK & $\times$ & DNATR. & $\sin$ & STTKTTSCR \\
\hline \multirow{6}{*}{3} & \multirow{5}{*}{ PrMatilis tar } & If & Mipnijtres. & 5 & 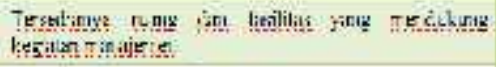 \\
\hline & & \multirow[t]{2}{*}{17} & \multirow{2}{*}{ 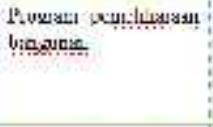 } & $\leq 1$ & 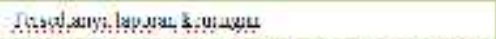 \\
\hline & & & & 5 & 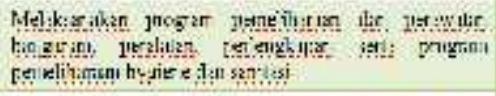 \\
\hline & & \multirow[t]{2}{*}{$1 \mathrm{~s}$} & \multirow[t]{2}{*}{$\begin{array}{l}\text { lecming } \\
\text { kest:msin }\end{array}$} & $\therefore !$ & 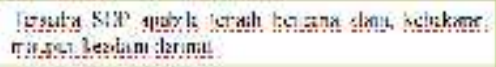 \\
\hline & & & & st & 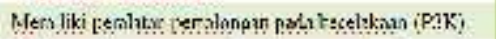 \\
\hline & & 13 & 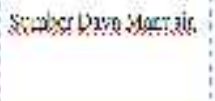 & $\therefore$ & 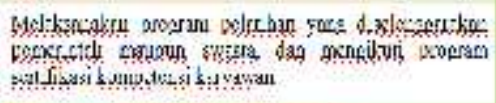 \\
\hline \multicolumn{4}{|c|}{ AXI'EL } & 3 & H.Wil \\
\hline \multicolumn{4}{|c|}{ L.YSUL } & 19 & ILASLIILAI is 110 \\
\hline \multicolumn{4}{|c|}{ STTLVSIR } & 14 & TLAST, VII.A1 111 - 18. \\
\hline \multicolumn{4}{|c|}{ 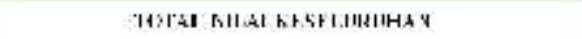 } & 7 & \\
\hline
\end{tabular}

Gambar 6. Aspek Produk dalam Pengelolan Homestay

Sumber: Pedoman Pengelolaan Homestay di DIY (2015)

Faktor penting terakhir dalam pengelolaan homestay adalah pengelolaan. Gambar 6 menunjukan unsure-unsur yang harus ada dalam pengelolaan, antara lain: (1) Manajemen berikut ruang dan fasilitas yang mendukung kegiatan manajemen, (2) Program pemeliharaan bangunan yang dilaksanakan secara serius untuk menjaga fungsi asset, hygiene dan sanitasi homestay disertai laporan keuangan yang terkelola rapi, (3) Pengelolaan keamanan dan keselamatan, minimal tersedia peralatan Pertolongan Pertama Pada Kecelakaan (PPPK) dan Standar Operasional Prosedur (SOP) apabila terjadi bencana, (3) Pengelolaan Sumber daya Manusia (SDM) dengan melaksanakan program 
pelatihan yang telah diberikan pemerintah, maupun swasta, serta mengikuti program sertifikasi kompetensi.

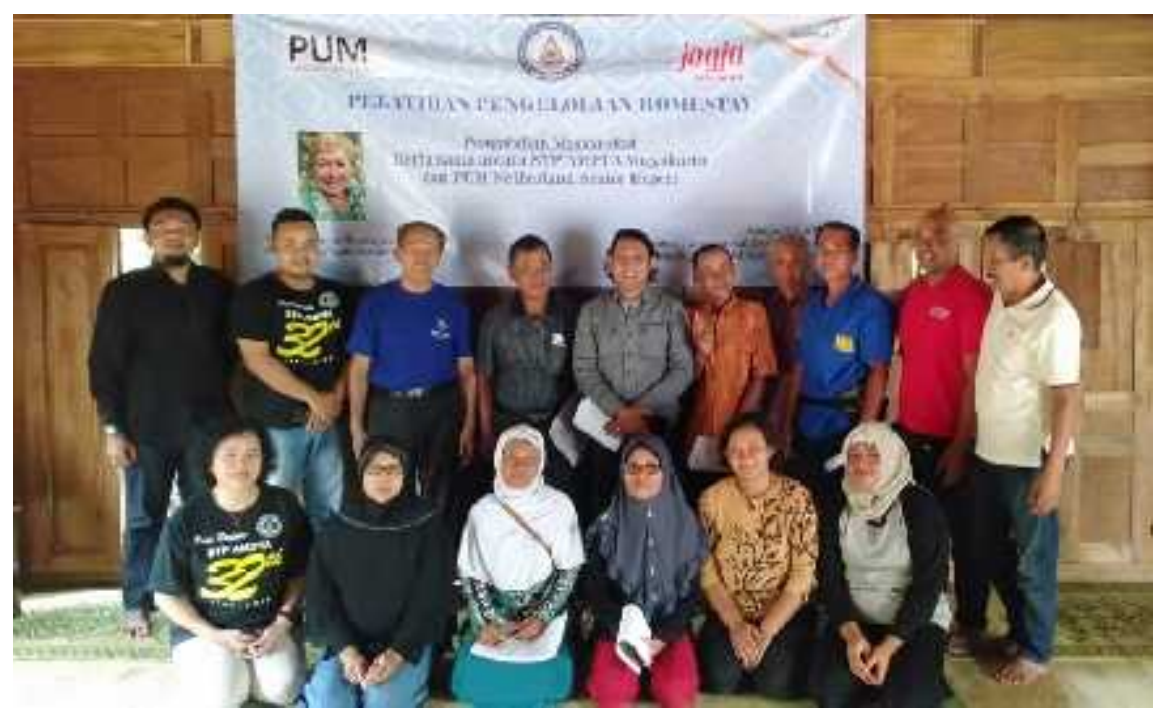

Gambar 7. Dokumentasi Kegiatan Pelatihan Pengelolaan Homestay

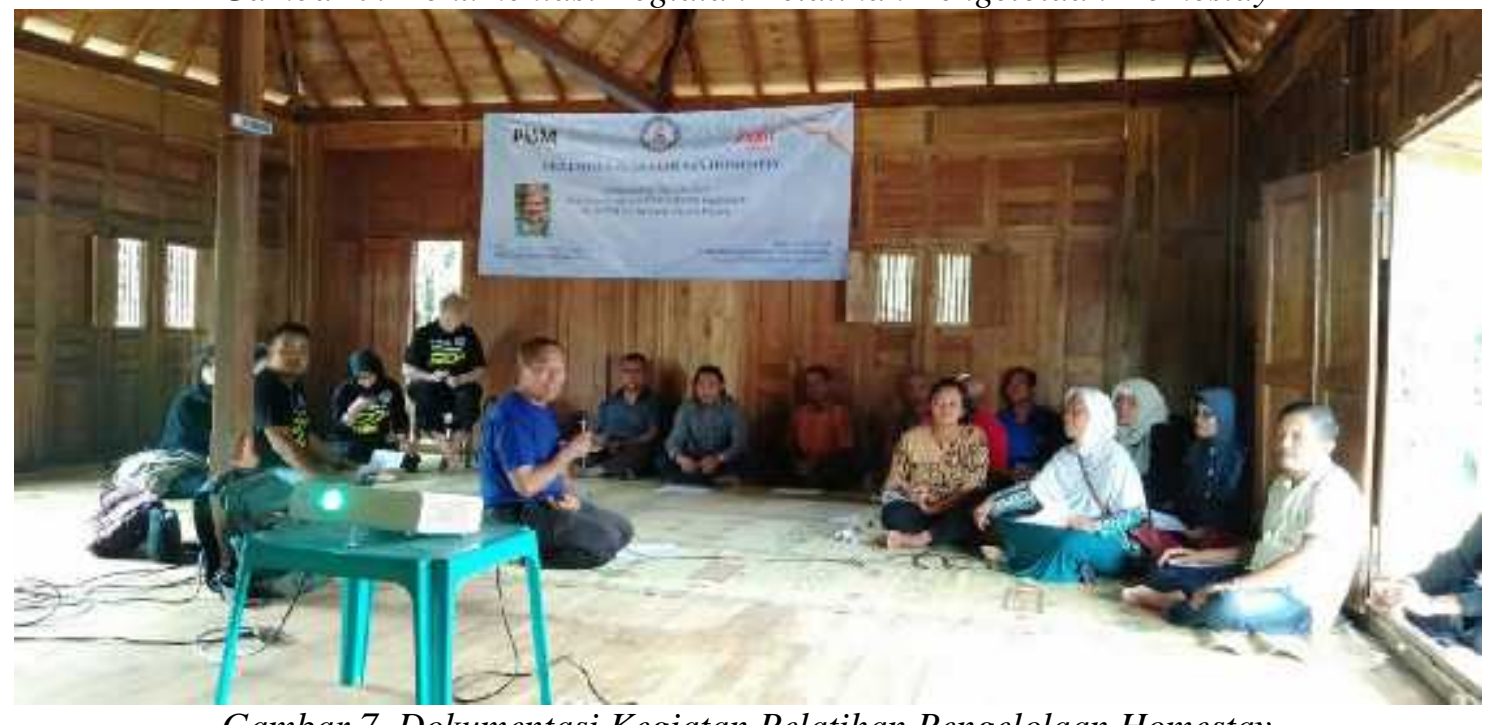

Gambar 7. Dokumentasi Kegiatan Pelatihan Pengelolaan Homestay

Secara keseluruhan pengabdian masyarkat ini berjalan lancar, peserta juga sangat antusias dalam mengikuti kegiatan ini dari awal presentasi hingga akhir acara yang ditutup dengan diskusi. Adapun kendala yang ditemui adalah seringkali pertanyaan-pertanyaan yang diajukan dalam sesi dikusi panel masih sering meluas. Hal ini dapat dikarenakan peserta benar-benar masih awan dengan segala permasalahan terkait dengan usaha penginapan, khususnya usaha homestay yang secara karakteristik operasional sangat berbeda jika dibandingkan dengan jenis usaha penginapan lain seperti hotel dan guest house.

Usaha penginapan jenis homestay, menuntut adanya kontak tuan rumah dan tamu yang lebih banyak dan lebih sering jika dibandingkan dengan usaha hotel ataupun guest house. Karena pada homestay wisatawan tinggal bersama pemilik rumah selaku induk semang. Berbeda dengan guest house, tamu menginap di guest house lebih jarang kontak dengan pemilik guset house. Implikasinya, warga selaku calon pemilik usaha homestay, selain harus memperhatikan pengelolaan yang berwujud aset fisik, juga dituntut untuk benar-benar serius dan siap untuk berlatih pelayanan.

Sebagai calon pelaku usaha jasa pariwisata, warga juga diharapkan siap dengan dampak kegiatan usaha yang dilakukan. Diantaranya kondisi sosial kampung yang mungkin akan menjadi semakin 
ramai dengan wisatawan. Untuk itu juga perlu direncanakan untuk kesepakatan jam malam dan sebagainya dengan pengurus desa wisata..

\section{Simpulan}

Homestayyang dirintis di Desa Wisata Donokerto diharapkan akan mampu menjadi salah satu sumber pendapatan utama bagi masyarakat.Mengingat keberadaan homestaydi desa wisata merupakan kebutuhan dasar bagi setiap wisatawan yang ingi berkunjung untuk menikmati daya tarik desa.

Oleh karena itu, perlu diwujudkan pengelolaan homestay yang tepat sehingga kegiatan pengabdian masyarakat wisata di Desa Donokerto tidak cukup sampai disini. Kegiatan masyarakat selanjutnya harus terus dilanjutkan dengan mempertimbangkan dinamika pariwisata yang berkembang di masyarakat Desa Donokerto.

\section{Ucapan Terima Kasih}

Kami mengucapkan terimakasih yang sebesar-besarnya kepada Sekolah Tinggi Pariwisata Ampta melalui Lembaga Penelitian dan Pengabdian kepada Masyarakat yang telah memfasilitasi kegiatan ini sehingga kegiatan pengabdian masyarakat ini dapat dilaksanakan dengan lancar.

Ucapan terimaksih juga kami sampaikan kepada PUM Netherlands Senior Expertsmelalui Ms. Wilhemina Van Koningsbrugge yang telah membantu memberikan pengarahan selama kegiatan pengabdian berlangsung. Serta tidak lupa ucapan kepada Pemerintah Desa serta masyarakat Desa Donokerto yang telah mendukung dan mengikuti kegiatan pengabdian ini dengan penuh antusias.

\section{Referensi}

Anonim. (2019). Donokerto, Turi, Sleman. Tersedia https://id.mwikipedia.org, diakses tanggal 16 Juni 2019.

Anonim. (2015). Pedoman Penyelenggaraan Homestay di DIY. Tersedia https://scribd.com, diakses tanggal 16 Juni 2019.

Arief, A. M. R., \& Aminudin, A. R. (2015). Pelaksanaan Pengelolaan Homestay di Desa Lubuk Kembang Bunga Kawasan Eko Wisata Tesso Nilo Kabupaten Pelalawan Provinsi Riau. Jurnal Online Mahasiswa Fakultas Ilmu Sosial dan Ilmu Politik Universitas Riau, 2(2), 1-13. Tersedia https://www.neliti.com/publications/32483/pelaksanaan-pengelolaan-homestay-di-desa-lubukkembang-bunga-kawasan-eko-wisata, diakses 16 Juni 2017.

CNN Indonesia. (2017). Kementerian PUPR Dorong Pembangunan Homestay Desa Wisata. Tersedia https://www.cnnindonesia.com/gaya-hidup/20170519143808-307215963/kementerian-pupr-dorong-pembangunan-Homestay-desa-wisata, diakses 16 Juni 2017.

Hermawan, H \& Brahmanto, E. (2018). Geowisata: Perencanaan Pariwisata Berbasis Konservasi. Pekalongan: Penerbit NEM.

Hermawan, H \&Ghani, Y.A. (2019). Geowisata: Solusi Pemanfaatan Geologi yang Berwawasan Lingkungan. Jurnal sains Terapan Pariwisata, 3(3), 391-408. Tersedia http://journal.polteksahid.ac.id/index.php/jstp/article/view/306, diakses 16 Juni 2017.

Hermawan, H., Brahmanto, E., Hamzah, F. (2018). Pengantar Manajemen Hospitality. Pekalongan: Penerbit NEM.

Jamaludin., Mariam., Othman, N., Awang, A.R. (2012). Community Based Homestay Programme: A Personal Experience. Procedia Social and Behavioral Sciences,42, 451459.Tersediahttps://www.sciencedirect.com/science/article/pii/S1877042812010920, diakses 16 Juni 2017.

Ningrum, L., Boediman, S.F., Octarina, D. (2019). Homestay Desa Wisata di Indonesia: Bagaimana Persepsi Masyarakat Kota? Jurnal Pariwisata, 16(3), 80-91. 